\title{
Molecular Characterization and Phenotypic Study of New Pleurotus djamor Isolate KKM 1
}

\author{
T. Praveen, R. Reihana, V.K. Parthiban and V. Ramamoorthy* \\ Department of Plant Pathology, Agricultural College and Research Institute, (Tamil Nadu \\ Agricultural University) Killikulam, Vallanadu, \\ Thoothukudi (Dist), Tamil Nadu, India \\ *Corresponding author
}

Recently we found new Pleurotus sp. isolate KKM 1 that grew on wood logs. The experiments were conducted to study its morphological and phenotypic characters of mycelium and basidiocarps of Pleurotus isolate KKM 1 compared with other cultivated

\begin{tabular}{|l|}
\hline Key w or d s \\
Pleurotus, \\
Molecular \\
characterization, \\
ITS, Phenotype \\
analysis \\
\hline Article Info \\
\hline Accepted: \\
20 July 2018 \\
Available Online: \\
10 August 2018 \\
\hline \hline
\end{tabular}
mushroom varieties such as $P$. eous var. APK1, and $P$. djamor var. MDU1 and $P$. florida. Pleurotus isolate KKM 1 was confirmed as Pleurotus djamor by ITS sequencing of rDNA region. Thus, the new Pleurotus sp. isolate KKM1 was named as P. djamor isolate KKM1.The mycelial growth of $P$. djamor isolate KKM 1appeared loose, nonrhizomorphic type and thin mycelium whereas other cultivated mushroom varieties such as $P$. djamor var. MDU1 and $P$. florida produced compact and rhizomorphic type of mycelium. Basidiocarps of P. djamor isolate KKM 1 was distinct from other Pleurotus spp. P. djamor isolate KKM 1produced fruiting bodies with rudimentary stipe or no stipe at all, whereas other tested Pleurotus spp. have visible stipe. Pileus diameter was the maximum in $P$. djamor isolate KKM1.P. djamor isolate KKM1 produced leathery type of pileus having less plectenchymatous tissue and its thickness is the minimum among the tested Pleurotus spp. P. eous var. APK1 produced pink coloured fruiting bodies whereas other species produced white colored basidiocarp. P. djamor isolate KKM 1 produced pileus with wavy margins/edges whereas in other Pleurotus spp. the margin/edges are smooth. Thus the present study shows the new P. djamor isolate KKM would be a potential isolate for mushroom cultivation and mushroom germplasm collection.

\section{Introduction}

Mushrooms are saprophytic fungi producing conspicuous sporocarps (fruiting bodies) and are collectively called as macrofungi. Mushroom has a large sporocarp, enough to be seen with the naked eye and can be picked up by hand (Chang, 2012). Oyster mushrooms are a diverse group of saprotrophic fungi belonging to the genus Pleurotus (Kong, 2004). Oyster mushroom can grow at moderate temperatures, ranging from 20 to $30^{\circ} \mathrm{C}$, and produces sporocarp at a humidity of $80-100 \%$, on various agricultural waste 
materials used as substrate. The climatic conditions and seasonal diversity is the most important factors for the cultivation of the oyster mushroom (Amin et al., 2007). Pleurotus cultivation has recently increased due to desired taste as well as numerous nutritional and medicinal benefits. Development of new mushroom strains that can be adapted to the hot climatic conditions, higher yield potential and prolonged shelf life are the present day needs of commercial cultivation.

Giving more emphasis on development of mushroom variety having short crop duration and high biological efficiency, the present study was carried out to characterize new Pleurotus sp. isolate KKM1.

\section{Materials and Methods}

Isolation and culturing of the new Pleurotus sp. isolate KKM1

Well grown disease free sporocarps were collected and kept on a sterile tissue paper for 2-3 hours to evaporate the moisture present in the mushroom. The mushroom was surface sterilized with $70 \%$ ethyl alcohol using absorbent cotton and it was split opened longitudinally into two halves. Using a new sterilized blade, a small piece of tissue was cut from the centre of the split mushroom at the junction point of the pileus and stipe. The sterilized PDA medium was amended with $100 \mathrm{ppm}$ of streptomycin sulphate to avoid bacterial contamination. When the temperature of the medium was cooled to bearable temperature $\left(60-70^{\circ} \mathrm{C}\right), 20 \mathrm{ml}$ was poured into sterile Petri plates $(90 \mathrm{~mm})$ and allowed to solidify. Three tissue pieces, taken from the junction point of pileus and stipe, were then inoculated on the PDA medium at equidistance in triangular position and incubated at $28^{\circ} \mathrm{C}$. The plates were observed daily for the growth of the fungus. All these works were carried out under aseptic conditions. The pure culture of the Pleurotus sp. isolate KKM1 was maintained on PDA slants for further use in this study. The stock cultures were maintained in PDA slants for long term storage under refrigerated conditions at $4^{\circ} \mathrm{C}$.

Commercially produced mushrooms cultivars viz., $P$. florida, $P$. djamor var. MDU1 and $P$. eous var. APK1 were used in this study as standard isolates for comparison. For isolation of mycelium from these three isolates, the same procedure as described above was followed. The culture of all strains was maintained in PDA slant for further studies.

Molecular characterization of Pleurotus sp. Isolation of total genomic DNA from Pleurotus sp.

Total genomic DNA was isolated from Pleurotussp.as described by(Lee et al., 1988)with slight modifications. About 100 $\mathrm{mg}$ of mycelial mat was used for the isolation of the DNA. The mycelium was dried well using the blotter paper and immersed in 95100 per cent ethanol for $10-15$ mins and then ethanol was blot-dried (Avin et al., 2013). Then the mycelium was ground with equal amount of acid-washed sand (for breaking the cell wall) using sterile pestle and mortar until mycelia tissue become paste. To ground mycelium, $1 \mathrm{ml}$ of $2 \mathrm{X}$ CTAB buffer (hexadecyl trimethyl ammonium bromide) was added and mixed well.750 $\mu \mathrm{l}$ of the mixture was taken in $1.5 \mathrm{ml}$ Eppendorf tubes and incubated at $65^{\circ} \mathrm{C}$ for $25-30$ mins. To that, $750 \mu \mathrm{l}$ of chloroform was added and vortexed for $5 \mathrm{sec}$, incubated for $10 \mathrm{mins}$ and centrifuged at 14,000 rpm for 15 minutes. The supernatant was collected and equal amount of isopropanol was added and incubated at $20^{\circ} \mathrm{C}$ for $30-45$ minutes or overnight for DNA precipitation. The samples were centrifuged at $14,000 \mathrm{rpm}$ for10 minutes to 
pellet the nucleic acids and washed with $70 \%$ ice cold ethanol. Finally the pelleted DNA was dried at $37^{\circ} \mathrm{C}$. Finally, the isolated DNA was re-suspended in $50 \mu \mathrm{l}$ of sterile water and quality and quantity of the isolated DNA was confirmed by resolving the DNA in the $1 \%$ agarose gel.

\section{ITS sequencing of Pleurotus spp.}

A PCR reaction was carried out using Emerald Amp® GT PCR master mix using genomic DNA of Pleurotus spp. as a template. ITS1-5.8S-ITS2 region of the rDNA was amplified using the primers ITS1 and ITS4. The following PCR conditions were followed. Initial denaturation at $94^{\circ} \mathrm{C}$ for 5 min; 35 cycles of denaturation at $94^{\circ} \mathrm{C}$ for 30 $\mathrm{sec}$, annealing temperature at $50^{\circ} \mathrm{C}$ for $30 \mathrm{sec}$ and extension at $72^{\circ} \mathrm{C}$ for $60 \mathrm{sec}$, and a final extension at $72^{\circ} \mathrm{C}$ for $10 \mathrm{~min}$. The PCR products were verified by electrophoresis in $1 \%$ agarose gel.

The Primers used for amplification of ITS region were

ITS1 - 5' TCCGTAGGTGAACCTGCGG 3' (forward primer)

ITS4 - 5' TCCTCCGCTTATTGATATGC3' (reverse primer)

Sequencing of ITS and identification of species of Pleurotus

The PCR products were purified using FavorPrep GEL/ PCR purification kit.The purified ITS product was sequenced at Eurofins genomics India Pvt. Ltd. Bangalore. Then DNA sequences, in which clear chromatogram obtained, were made in Fasta format. This was used as input sequence (Query sequence) in nucleotide blast analysis program at NCBI database. The output was retrieved from the bioinformatics analysis tool and then, the organism showing major score from the output is considered as the closely related species to the test fungus used in the study.

\section{Mycelial growth pattern of Pleurotus spp.}

To study the cultural and phenotypic characters of mycelial growth of Pleurotus sp. isolate KKM 1 along with the standard cultures, five millimetre culture discs were cut with sterilized cork borer from advancing margins of the colonies of fungus and inoculated on PDA plates supplemented with streptomycin sulphate $(100 \mathrm{ppm})$. The plates were incubated at $28^{\circ} \mathrm{C}$. Three replications were maintained for each temperature. Radial growth of the mycelium was recorded when anyone of the Petri plates of the treatments was completely covered by mycelium.

\section{Morphological characterization of basidiocarp of the Pleurotus spp.}

The following phenotypic characters were gathered on Pleurotus sp. isolate KKM 1 with existing cultivars viz., P.florida, $P$. djamor var. MDU-1 and P. eous var. APK 1. Information on morphological characters viz., diameter of the pileus, pileus phenotype especially its margin/edge shape, stipe length, colour of the basidiocarp, thickness of the pileus, number of gills, and number of stipe present per bunch was recorded.

\section{Results and Discussion}

Molecular characterization of Pleurotus sp. isolate KKM1

Identification and confirmation of Pleurotus sp. isolate KKM1 by molecular technique

Based on the morphological character of basidiocarp, most of the mushroom fungi are identified at genus level. Likewise, the new 
mushroom used in the study was identified at genus level as Pleurotus sp. and named as Pleurotus sp. isolate KKM1. Identification of unknown species of Pleurotus can be done by molecular technique such as ITS1-5.8S-ITS4 sequencing analysis which is one of the commonly used molecular methods for the identification of fungus at species and subspecies level (Bruns et al., 1991; Hibbett, 1992).

Genomic DNA from the Pleurotus isolate KKM1,wasisolated by CTAB method of DNA isolation. High molecular weight band was visualized on the agarose gel (Fig. 1A). Genomic DNA was used for amplification of ITS 1-5.8S-ITS 2 rDNA sequence region using primer pair ITS 1 and ITS 4.The PCR fragments of $700 \mathrm{bp}$ size fragment was visualized as single band in agarose gel stained with ethidium bromide (Fig. 1B).

ITS 1-5.8S-ITS2 PCR products were cleaned up with PCR cleaned up kit to remove the residual primers, polymerase and salts in the PCR product, the cleaned up products were sequenced at Eurofin genomic private Ltd, India. The sequence was used for DNA database search using BLAST program. The BLAST search analysis of ITS 1-5.8S-ITS2 region of Pleurotus isolate KKM 1 matched with that of Pleurotus djamor at $99 \%$ identified in the database.

Identification using the sequences of ITS region is typically the most useful method and also this method is applicable for molecular systematics at the species levels(De Beeck et al., 2014). For identification of specific genera and species, the rDNA repeat unit, consisting of the subunits $18 \mathrm{~S}, 5.8 \mathrm{~S}$ and $28 \mathrm{~S}$ rDNA interrupted by the internal transcribed spacer (ITS) and the intergenic spacer (IGS) is employed due to their specific sequences as a target region. The advantage of ITS sequencing is the identification of any unknown fungal isolate using the database containing the corresponding sequence of previously identified fungal species or closely related species (Schmidt et al., 2012). From the new Pleurotus sp. isolate KKM1, ITS sequence was PCR amplified and DNA fragments of $700 \mathrm{bp}$ was eluted and sequenced. The results of ITS analysis indicated that the sequence was similar to that of ITS1-5.8S-ITS2 region of P. djamor. Thus, this new Pleurotus isolate KKM1 was named as Pleurotus djamor isolate KKM1.

\section{Mycelial growth phenotype of Pleurotus spp.}

On PDA medium, mycelial growth of $P$. djamor isolate KKM1 appeared loose, nonrhizomorphic type and thin mycelium whereas, $P$. djamor var. MDU1 and $P$. florida produced compact and rhizomorphic type of mycelium because they produce more mycelial branches from one place. P.eous var. APK1 showed polar growth defects and that formed constricted growth with cottony fluffy mycelium (Fig. 2). Similarly, the mycelium of $P$. djamor isolate KKM1 appeared loose, nonrhizomorphic type on the spawn substrate whereas all other Pleurotus spp. tested including $P$. eous produced compact and rhizomorphic type of mycelium.

Among the Pleurotus spp. tested, P.djamorvar MDU1 grew well and attained the maximum growth of $89.00 \mathrm{~mm}$ on PDA medium followed by $P$. florida and $P$. djamor isolate KKM 1with the mycelial growth of 78 and $76 \mathrm{~mm}$ respectively. $P$. eous var. APK1 grew slowly on PDA medium (Table 1). Mishra et al., (2015) reported similar type of mycelial growth pattern in several Pleurotus spp. The pattern of mycelial growth in $P$. citrinopileatus was thick and fluffy, whereas, that in $P$. fossulatus, $P$. flabellatus and $P$. sapidus were slightly fluffy. $P$. djamor showed the cottony growth. In the present 
also, all the tested Pleurotus spp. except $P$. djamor isolate KKM1 produced thick cottony mycelial growth.

\section{Phenotypic characterization of basidiocarp of Pleurotus spp.}

The characterization of various Pleurotus isolate had been attempted by many scientists from time to time. In the present study, phenotypic characters of basidiocarps of four Pleurotus spp. were studied. Each Pleurotus sp. has typical distinguishing characters for easy identification. They are described below

\section{Stipe length}

Among the four Pleurotus spp. tested, $P$. djamor var. MDU1 produced fruiting bodies with long stipe $(54.50 \mathrm{~mm})$, which was on par with $P$. florida $(52.25 \mathrm{~mm})$. $P$. djamor isolate KKM 1produced fruiting bodies with rudimentary stipe or no stipe at all. P. eous var.APK1 produced fruiting bodies having small sized stipe $(26.50 \mathrm{~mm})$ (Fig. 3; Table 2).

\section{Diameter of the pileus}

Pileus diameter was maximum inP. Djamor isolate $\mathrm{KKM} 1(119.25 \mathrm{~mm})$ followed by P.eous var. APK-1 $(97.75 \mathrm{~mm})$ and $P$ djamor var. MDU1 $(91.00 \mathrm{~mm})$. P. florida had small sized pileus with the diameter $88.25 \mathrm{~mm}$ (Fig.
3; Table 2).

\section{Thickness of fruiting body}

Thickness of the pileus depends on the amount of plectenchymatous tissue present in the pileus. The thickness of the pileus was measured near the junction point of pileus and stipe. P. florida produced fruiting bodies with maximum pileus $(12.62 \mathrm{~mm})$. This was followed by P. djamor var. MDU1 and P.eous var.APK1 having the thickness of $8.62 \mathrm{~mm}$ and $7.87 \mathrm{~mm}$ respectively. $P$. djamor isolate KKM1 produced leathery type of pileus having less plectenchymatous tissue and the thickness of $5.62 \mathrm{~mm}$ (Table 2).

\section{Margin of fruiting body}

$P$. djamor isolate KKM1 has the pileus with wavy margin whereas $P$. florida, $P$. djamor var. MDU1. And P.eous var. APK1 have pileus with smooth margins (Fig. 3; Table 2).

\section{Colour of fruiting body}

$P$. eous var. APK1 produced pink coloured fruiting bodies. $P$. florida produced creamy white coloured fruiting bodies. Whereas $P$. djamor isolate KKM1 and $P$. djamor var. MDU1 produced white coloured fruiting bodies (Fig. 3; Table 2).

Table.1 Effect of temperature on the mycelial growth of Pleurotus spp. on PDA medium

\begin{tabular}{|l|c|c|}
\hline Pleurotusspp. & \multicolumn{2}{|c|}{ Mycelial growth (mm)* } \\
\cline { 2 - 3 } & $4^{\text {th }}$ day & $7^{\text {th }}$ day \\
\hline P. eous var.APK-1 & $23.00^{\mathrm{b}}$ & $34.75^{\mathrm{c}}$ \\
\hline P. djamor var. MDU-1 & $62.50^{\mathrm{a}}$ & $89.00^{\mathrm{a}}$ \\
\hline P. florida & $60.50^{\mathrm{a}}$ & $78.25^{\mathrm{b}}$ \\
\hline P. djamor isolate KKM 1 & $59.25^{\mathrm{a}}$ & $76.25^{\mathrm{b}}$ \\
\hline
\end{tabular}

* Mean of four replications

The treatment means are compared using Duncan Multiple Range Test (DMRT).

In a column, mean values followed by a common letter $(s)$ are not significantly different $(P=0.05)$. 
Table.2 Phenotypic characterization of basidiocarp of P.djamorisolate KKM 1 and other Pleurotusspp

\begin{tabular}{|c|c|c|c|c|c|c|c|c|c|c|}
\hline \multirow[t]{2}{*}{ Pleurotus spp. } & \multicolumn{3}{|c|}{ Diameter of the pileus $(\mathrm{mm}) *$} & \multicolumn{3}{|c|}{ Length of stripe $(\mathrm{mm})^{*}$} & \multirow{2}{*}{$\begin{array}{l}\text { appearance of } \\
\text { pileus margin }\end{array}$} & \multirow{2}{*}{$\begin{array}{c}\text { Thickness } \\
\text { of pileus } \\
(\mathrm{mm})^{*}\end{array}$} & \multirow{2}{*}{$\begin{array}{l}\text { Number } \\
\text { of } \\
\text { gills } / \mathrm{cm}^{2}\end{array}$} & \multirow{2}{*}{$\begin{array}{l}\text { Colour of } \\
\text { fruiting } \\
\text { body }\end{array}$} \\
\hline & $\begin{array}{c}\text { Primordial } \\
\text { stage }\end{array}$ & $\begin{array}{c}\text { Mature } \\
\text { stage }\end{array}$ & $\begin{array}{c}\text { Harvesting } \\
\text { stage }\end{array}$ & $\begin{array}{c}\text { Primordial } \\
\text { stage }\end{array}$ & $\begin{array}{c}\text { Mature } \\
\text { stage }\end{array}$ & $\begin{array}{c}\text { Harvesting } \\
\text { stage }\end{array}$ & & & & \\
\hline $\begin{array}{c}\text { P.eous } \\
\text { var.APK-1 }\end{array}$ & $11.25^{\mathrm{b}}$ & $57.75^{\mathrm{C}}$ & $97.75^{\mathrm{b}}$ & $12.35^{\mathrm{a}}$ & $21.75^{\mathrm{c}}$ & $26.50^{c}$ & Smooth & $7.87^{\mathrm{c}}$ & $21.00^{\mathrm{b}}$ & Pinkish \\
\hline P.florida & $5.25^{\mathrm{c}}$ & $86.50^{\mathrm{a}}$ & $88.25^{\mathrm{c}}$ & $10.25 \mathrm{ab}$ & $49.75^{\mathrm{a}}$ & $52.25^{\mathrm{a}}$ & Smooth & $12.62^{\mathrm{a}}$ & $19.50^{\mathrm{c}}$ & $\begin{array}{c}\text { Creamy } \\
\text { white }\end{array}$ \\
\hline $\begin{array}{l}\text { P.djamor var. } \\
\text { MDU-1 }\end{array}$ & $16.50^{\mathrm{a}}$ & $55.25^{\mathrm{b}}$ & $91.00^{b}$ & $14.50^{\mathrm{a}}$ & $43.00^{b}$ & $54.50^{\mathrm{a}}$ & Smooth & $8.62^{b}$ & $11.50^{\mathrm{d}}$ & White \\
\hline $\begin{array}{l}P . \text { djamor } \\
\text { isolate } \\
\text { KKM } 1\end{array}$ & $15.25^{\mathrm{a}}$ & $80.75^{b}$ & $119.25^{\mathrm{a}}$ & $5.55^{\mathrm{b}}$ & $11.50^{\mathrm{d}}$ & $15.12^{b}$ & $\begin{array}{c}\text { Wavy and } \\
\text { broken }\end{array}$ & $5.62^{d}$ & $23.50^{\mathrm{a}}$ & White \\
\hline
\end{tabular}

*Mean of four observations

Treatment means are compared using Duncan multiple range test(DMRT).

In a column, mean values followed by a common letter(s) are not significantly different $(\mathrm{P}=0.05)$ 
Figure.1 Molecular characterization new Pleurotus sp. isolate KKM1

A

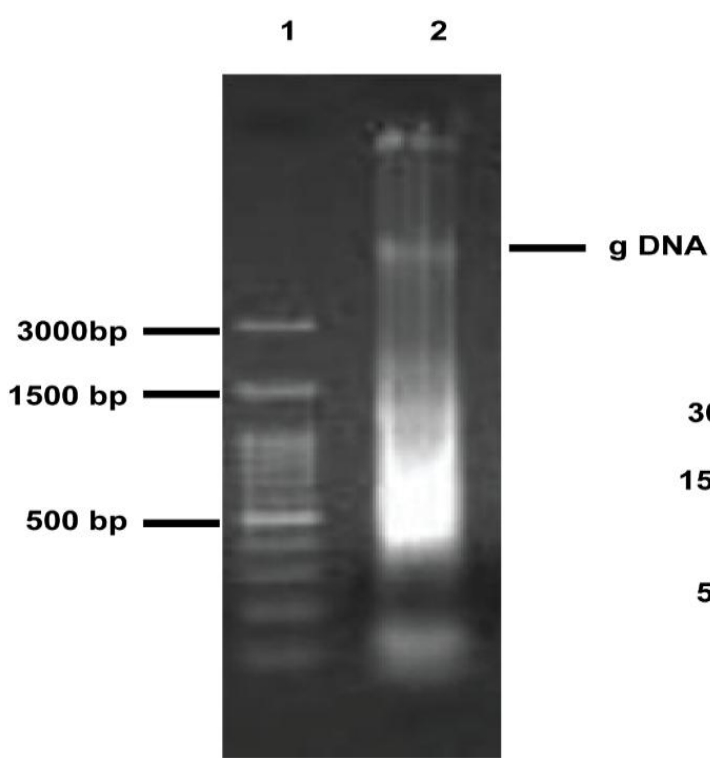

B
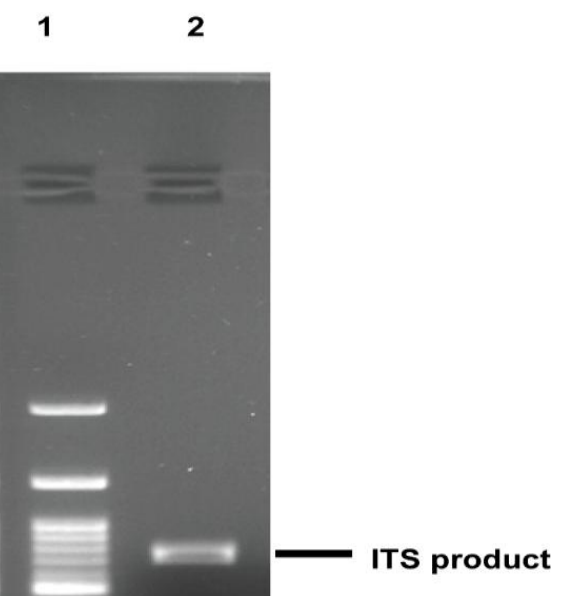

500 bp -

A). Isolation of genomic DNA from Pleurotus sp. isolate KKM1. Lane 1: Lambda ladde Lane 2: gDNA of Pleurotus isolate KKM

B) Amplification of ITS1-5.8S-ITS2 region from the genomic DNA of Pleurotus sp. isolate KKM1. Lane 1: $100 \mathrm{bp}$ ladder and 1 and Lane 2:ITS of Pleurotus isolate KKM 1

Figure.2 Mycelial growth pattern of Pleurotus spp. on PDA medium

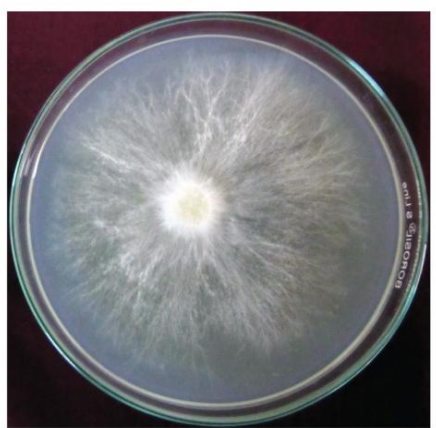

P. djamor isolate KKM 1

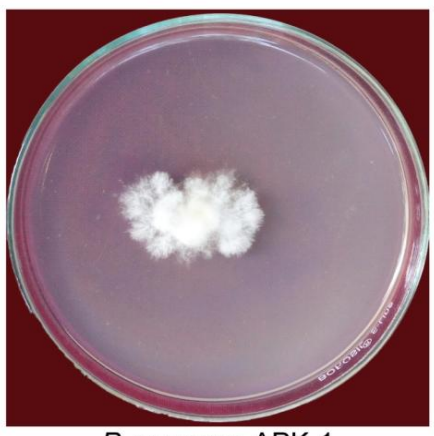

P. eous var. APK-1

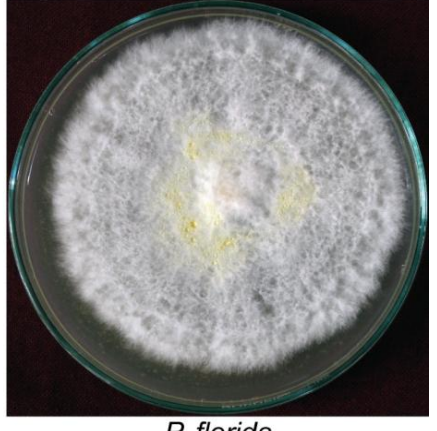

P. florida

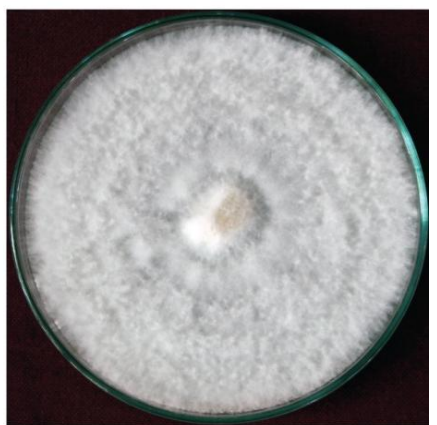

P. djamor var. MDU-1 
Figure.3 Phenotypic characterization of basidiocarps of Pleurotus spp
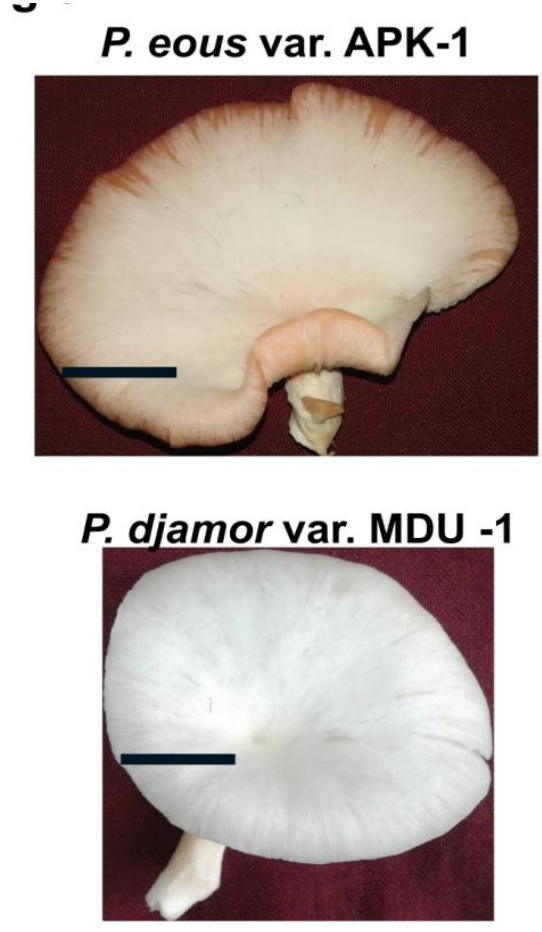
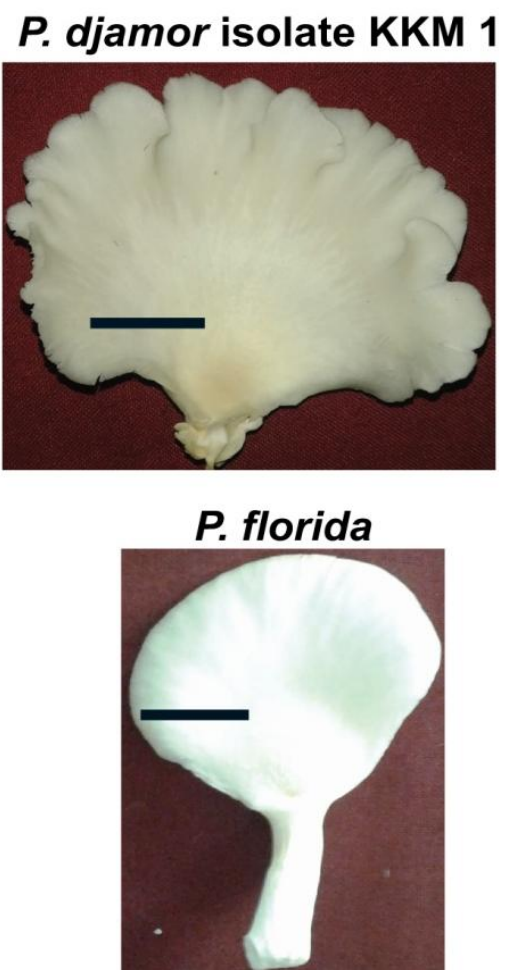

$88.25 \mathrm{~mm}$. Among the various Pleurotus spp., tested, P. flabellatus showed the maximum pileus length of $139 \mathrm{~mm}$ followed by $P$. ostreatus $(132 \mathrm{~mm})$ and minimum pileus diameter was observed in $P$. sajorcaju with $54 \mathrm{~mm}$ (Mishra et al., 2015). Shukla and Jaitly (2011) characterized the seven different Pleurotus species based on the five different morphological traits such as stipe length $(\mathrm{cm})$, cap diameter $(\mathrm{cm})$, margin of fruit body, peripheral architecture of the pileus, colour of fruit body, total yield $(\mathrm{kg})$, carbohydrate content $(\%)$ and protein content $(\%)$. Out of seven Pleurotus spp., five species were named as follows $P$. citrinopileatus, $P$. djamor, P. florida, H. ulmarius and P. sajorcaju. They also observed great diversity on morphological characters among all the five species of Pleurotus.

Usually, many Pleurotus spp. produce smooth pileus with long stipe. But $P$. djamor isolate KKM1 has large white colour pileus having 
wavy margin and has small or rudimentary stipe. Thus, it is concluded that this new $P$. djamor isolate KKM1 has typical phenotypic features and characteristic mycelial pattern of loose non-rhizomorphic mycelial characters that distinguishes it from other Pleurotus spp. and this $P$. djamor isolate KKM1 could be used as new culture in mushroom germplasm collection and mushroom cultivation.

\section{References}

Amin, S.M.R., Sarker, N.C., Khair, A. and Alam, N.2007. Detection of novel supplements of paddy straw substrate on oyster mushroom cultivation. Bangladesh Journal of Mushroom, 1: 33-37.

Avin, F. A., Bhassu, S. and Vikineswary, S. 2013. A simple and low-cost technique of DNA extraction from edible mushrooms examined by molecular phylogenetics. Research on Crops, 14(3): 897-901.

Bruns, T. D., White, T. J. and Taylor, J. W. 1991. Fungal molecular systematics. Annual Review of Ecology and systematics, 22(1): 525-564.

Chang, S.T. 2012. Foreword. Mushroom Science XVIII. Jinxia Zhang; Hexiang Wang and Mingjie Chen (eds). Proceedings the Internl. Society for Mushroom Science.

De Beeck, M. O., Lievens, B., Busschaert, P., Declerck, S., Vangronsveld, J. and
Colpaert, J. V. 2014.Comparison and validation of some ITS primer pairs useful for fungal metabarcoding studies. PLoS One, 9(6): e97629.

Hibbett, D. 1992. Ribosomal RNA and fungal systematics. Transaction of Mycological society of japan, 33: 533-556.

Lee, S.B., Milgroom, M.G. and Taylor, J.W. 1998. A rapid high yield mini-prep method for isolation of total genomic DNA from fungi. Fungal Genetics Newsletter, 35: 23-24.

Kong, W.S. 2004.Descriptions of commercially important Pleurotus species. In: Mushroom world (Ed.). Oyster mushroom cultivation. Part II.Oyster mushrooms. Seoul: Heineart Incorporation, pp.54-61. (Mushroom growers' handbook, 1).

Mishra, R., Shahid, M., Pandey, S., Pandey, M. and Singh, M. 2015. Characterization of Pleurotus sp. of mushroom based on phenotypic, biochemical and yield parameter. African Journal of Microbiology Research, 9(13): 934-937.

Schmidt, O., Gaiser, O. and Dujesiefken, D. 2012. Molecular identification of decay fungi in the wood of urban trees. Eur. J. For. Res., 131: 885-891.

Shukla, S. and Jaitly, A. 2011. Morphological and biochemical characterization of different oyster mushroom (Pleurotus spp.). Journal of Phytology, 3(8):18-20.

\section{How to cite this article:}

Praveen, T., R. Reihana, V.K. Parthiban and Ramamoorthy, V. 2018. Molecular Characterization and Phenotypic Study of New Pleurotus djamor Isolate KKM 1. Int.J.Curr.Microbiol.App.Sci. 7(08): 3574-3582. doi: https://doi.org/10.20546/ijcmas.2018.708.361 